\title{
Cross Infection between Rice and Wheat Blast Pathogen Pyricularia oryzae
}

\author{
M A Monsur ${ }^{*}$, M Ahmed ${ }^{1}$, A Haque ${ }^{1}$, Q S A Jahan ${ }^{1}$, T H Ansari ${ }^{1}$, M A Latif ${ }^{1}$, \\ N C D Borma ${ }^{2}$, M A Ali ${ }^{1}$, M S Kabir ${ }^{1}$ and B R Banik ${ }^{1}$
}

\begin{abstract}
Cross infection between rice and wheat blast fungi was investigated in a series of experiments conducted under controlled glasshouse condition following a completely randomized design. Two rice (BRRI dhan29 and LTH) and two wheat (BARI Gom25 and BARI Gom26) varieties were grown in plastic trays as sole and rice-wheat mixed crop culture. Plants were artificially inoculated using virulent isolates of rice and wheat blast fungi. It was observed that irrespective of variety and crop culture technique, all the isolates of wheat blast fungus caused significant $100 \%$ plant infection on leaf typical leaf blast symptoms appeared on wheat seedlings but no blast symptom on rice. Conversely, the test-isolates of rice blast fungus did not produce any disease reaction on wheat seedlings, though leaf blast was observed on $100 \%$ rice plants. Therefore, we conclude that rice blast pathogen population is different from those of wheat blast pathogen (Pyricularia oryzae).
\end{abstract}

Keywords: Cross infection, rice, wheat blast, pathogen

\section{INTRODUCTION}

Magnaporthe oryzae (teleomorph) (Herbert) Barr (anamorph: Pyricularia oryzae) Couch and Kohn, 2002) is one of the most important plant pathogenic fungi having an exceptional capacity of rapidly changing its genetic makeup resulting in new pathogenic variants (races) (Dean et al., 2012; Khan et al., 2016). It is the causal agent of rice blast, one of the most devastating diseases of rice (Oryzae sativa L.) observed in most of the rice growing-countries across the world (Kihoro et al., 2013). The pathogen can cause infection on leaves, stems, peduncles, panicles, seeds and even roots. This disease is the potential threat that may cause crop failure and yield loss. Thus it has been ranked among the most important rice diseases.

Blast is also a major disease of wheat (Triticum aestivum L.) in many South American countries (Goulart et al., 1992; Goulart and Paiva, 2000; Goulart et al., 2007; Kohli et al., 2011). However, on wheat, the disease is caused by Magnaporthe oryzae f. sp. tritici. The pathogen has the potential to infect all above-ground parts of wheat plant (Igarashi, 1991). However, while leaf infection, varietal characteristics may play important roles epidemiologically (Cruz et al., 2015). The most significant symptom of wheat blast in the field is the premature bleaching of spikelets (Igarashi, 1991; Urashima, 2010). In severe cases, the entire head is damaged. If head infection occurs early grain production can be critically lost. Spike infection caused by blast is often confused with Fusarium head blight of wheat. As the pathogen attacks the rachis, rather than attacking individual spikelets in case of head blight (Duveiller et al., 2012).

Wheat blast was first reported in 1985 in Paraná, Brazil (Igarashi et al., 1986) and has since spread throughout many wheat-producing areas of Brazil and to the neighboring countries such as Bolivia and Paraguay (Goulart et al., 2007; Kohli et al., 2011). Recently in 2016, in Bangladesh, wheat blast was reported for the first time in south-western districts such

${ }^{1}$ Bangladesh Rice Research Institute, Gazipur. ${ }^{2}$ Wheat Research Center, BARI, Nashipur, Dinajpur. *Corresponding author's E-mail: monsurpath@gmail.com 
as Jessore, Kushtia, Chuadanga, Meherpur, Jhenaidah, Magura, Barisal and Bhola (The Daily Star, 2016). The disease caused severe yield loss in the affected areas. Blast infected field in Bangladesh Agricultural Development Corporation (BADC) seed producing farm was burnt even (Monsur et al, 2016).

Blast fungus is disseminated by air and seeds. Seed transmission is considered to be a feature that is significant for its dispersal by humans (Kato, 1994). Besides, there are several strains of $M$. oryzae which tend to display a degree of host specificity and they have been divided into pathotypes based on their host preference (Cruz et al., 2016). The strains that commonly occur on wheat in South America have been placed into the Triticum pathotype (MoT) which are genetically distinct from the strains of Oryza pathotype infecting rice. To date, the strains of Oryza pathotype is not known to cause disease on wheat and viceversa (Prabhu et al., 1992; Orbach et al., 1996; Urashima et al., 1999; Farman, 2002; Maciel et al., 2014).

Wheat blast symptoms and its causal agent were not previously reported in Bangladesh. Therefore, there is a great deal of controversy how this disease invaded in Bangladesh. We considered three probable reasons might have influenced or caused wheat blast invasion in Bangladesh. Firstly, virulent strains of $M$. oryzae tritici might have been introduced from South America as a seed-transmitted pathogen escaping the quarantine regulations. Secondly, virulent strains of $M$. oryzae tritici have evolved from pre-existing avirulent strains in Bangladesh. Finally, strains of minor cereals blast fungus (Pyricularia oryzae) that is already diverse and widespread in Bangladesh might become pathogenic to wheat under changing climatic conditions. Most recently, the final hypothesis drawn significant attention when Tiedemann (2016) presented his experimental results in a conference held in Nepal showing that wheat blast pathogen infected rice plants in Germany. Therefore, the phenomenon of such cross infection of rice blast pathogen deserves detailed investigation in context of
Bangladesh where rice blast fungus is present. Considering the above facts, this study was undertaken to investigate whether rice blast fungus can cause blast disease on wheat and vice-versa.

\section{MATERIALS AND METHODS}

\section{Experimental site and period}

A series of experiments were conducted in the laboratory and control facilities of Plant Pathology Division, Bangladesh Rice Research Institute (BRRI) during March-December 2016. Plants were exposed to relative humidity above $80 \%$ with constant temperature at $26^{\circ} \mathrm{C} \pm 1$.

\section{Fungal isolates}

Two rice blast isolates RBL332 (from BRRI dhan28) and RBL333 (from BRRI dhan64) were used in this experiment. Both the isolates were isolated from blast infected rice panicles collected from Gazipur, Bangladesh. Again, two wheat blast isolates WBL002 (from BARI Gom25) and WBL0011 (from BARI Gom26) were isolated from blast affected wheat head, which were collected from seed production farm of Bangladesh Agricultural Development Corporation (BADC) at Dottonagar in Jhinaedah district, Bangladesh.

\section{Single conidia isolation and culture}

Blast infected spikelets were sterilized by soaking with Clorox (5\%) for 3-5 seconds and then in ethanol (70\%) for 1 minute. Sterilized spikelets were gently rinsed with sterile water and dried samples with sterile tissue paper. Dried sterile spikelets were put on water soaked filter paper (Whatman International Ltd. Maidstone, England.) and incubated at $26^{\circ} \mathrm{C}$ for sporulation. Single spore were collected and cultured on prune agar medium.

\section{Growing host plants}

Two wheat varieties BARI Gom 25 and BARI Gom26 and two blast susceptible rice varieties BRRI dhan29 and LTH (Lijiangxintuanheigu) 
were used in this study. LTH is recognized as universal blast susceptible rice variety. Apparently healthy and disease free seeds of rice and wheat were soaked on blotting paper in plastic Petridish and incubated at room temperature for 48 hours for germination. Germinated seeds were sown in a plastic tray $(22 \mathrm{~cm} \times 16 \mathrm{~cm} \times 4 \mathrm{~cm})$ containing sterile loamy soil. However, for first two trials, wheat and rice varieties (BARI Gom25, BARI Gom26, BRRI dhan29 and LTH) were planted as sole crops. For another two trials, wheat and rice were planted as mixed cropping (BARI Gom 25 + BRRI dhan29 and BARI Gom26 + LTH). The plastic trays were then placed in a temperature controlled glass house operating at $26 \pm 1^{\circ} \mathrm{C}$. To ensure growth, the seedlings were watered daily and closely monitored for any insect infestation.

\section{Experimental design}

Experiments were laid out following completely randomized design (CRD) with three replicates in a glasshouse controlled temperature and relative humidity.

\section{Inocula preparation and inoculation}

Wheat blast isolates WBL002 and WBL0011 and rice blast isolate RBL332 and RBL333 were cultured separately on oat meal agar (1 liter distilled water, $50 \mathrm{~g}$ grinding oat powder, 20 $\mathrm{g}$ sugar, $20 \mathrm{~g}$ agar) for 17 days at $26^{\circ} \mathrm{C}$. The surface of the oat meal agar media on Petri dish was gently rubbed with a sterile paint brush to remove aerial mycelia. The cultures were then exposed to fluorescent light for three days at $26^{\circ} \mathrm{C}$ for inducing sporulation (Fatemi and Nelson, 1978).

For foliar spray inoculation, conidia from surface of sporulated oat meal culture were scraped gently with sterile paint brush and suspended in sterile water containing $0.01 \%$ Tween 20 . The suspension was filtered through two layer cheese cloth and conidial concentration was adjusted to $1 \times 10^{5} \mu \mathrm{L}$ water. The conidial suspension was sprayed using a hand sprayer on 21-day-old wheat and rice seedlings. Inoculated seedlings were incubated in a humid chamber at $25^{\circ} \mathrm{C}$ temperature for 24 hrs. Then the seedlings were transferred into a temperature controlled glass house operating at $28 \pm 1^{\circ} \mathrm{C}$.

\section{Data collection and analysis}

A week after inoculation, data were collected on plant infection (\%), leaf infection (\%), number of lesion per leaf, lesion size $\left(\mathrm{mm}^{2}\right)$ and disease severity scale. Size of elliptical leaf blast lesion was calculated from lesion length and width using the following formula: Lesion size $=3.14$ $\times($ Lesion length/2) $\times($ Lesion width/2). Disease severity scale was measured by using Standard Evaluation System (SES, IRRI, 2014). Data were average of 20 plants. Data were analyzed using a statistical software package Minitab version 16 (Tukeys test).

\section{RESULTS}

\section{Pathogenicity of wheat isolates on wheat and} rice plants (single crop culture)

Wheat blast isolates WBL002 and WBL0011 developed typical blast lesions on leaves of the wheat varieties BARI Gom25 (Fig. 1) and BARI Gom26. Both of the isolates caused the highest level $(100 \%)$ of plant and leaf infection on both wheat varieties used in this study (Table 1). Disease severity was also high (8.8 in 9 scale on BARI Gom25 with WBL002 and 8.0 in 9 scale on BARI Gom26 with WBL0011) for wheat blast isolates. However, the test-isolates varied to some extent in terms of the average number of lesion per leaf. On average, the isolate WBL002 developed 13.70 blast lesions per leaf on BARI Gom26 whereas it was 15.70 by WBL0011 isolate. Lesion size recorded with both of the wheat blast isolates were almost identical ( 12 $\mathrm{mm}^{2}$ on BARI Gom 25 and $\sim 10 \mathrm{~mm}^{2}$ on BARI Gom26). On the other hand, the wheat blast isolates WBL002 and WBL0011 did not develop any blast symptom (Plant infection=0, Leaf infection $=0$, No. of lesion per leaf $=0$, Lesion size $=0$ and Disease score $=0$ ) on the rice variety BRRI dhan29 (Table 1). 
Table 1. Effect of wheat isolates on wheat and rice single cropping.

\begin{tabular}{|c|c|c|c|c|c|}
\hline \multirow{2}{*}{ Isolate } & \multirow{2}{*}{ Parameter } & \multicolumn{2}{|c|}{ Wheat } & \multicolumn{2}{|c|}{ Rice } \\
\hline & & BARI Gom 25 & BARI Gom26 & BRRI dhan29 & LTH \\
\hline \multirow[t]{5}{*}{ WBL002 } & $\%$ plant infection & $100 \mathrm{a}$ & $100 \mathrm{a}$ & $0.00 \mathrm{~b}$ & $0.00 \mathrm{~b}$ \\
\hline & $\%$ leaf infection & $100 \mathrm{a}$ & $83.33 \mathrm{~b}$ & $0.00 \mathrm{c}$ & $0.00 \mathrm{c}$ \\
\hline & No. of lesion/leaf & 13.70 a & $10.55 \mathrm{~b}$ & $0.00 \mathrm{c}$ & $0.00 \mathrm{c}$ \\
\hline & Lesion size $\left(\mathrm{mm}^{2}\right)$ & $12.05 \mathrm{a}$ & $10.85 \mathrm{a}$ & $0.00 \mathrm{~b}$ & $0.00 \mathrm{~b}$ \\
\hline & Disease severity & $8.80 \mathrm{a}$ & $7.65 \mathrm{~b}$ & $0.00 \mathrm{c}$ & $0.00 \mathrm{c}$ \\
\hline \multirow[t]{5}{*}{ WBL0011 } & $\%$ plant infection & $100 \mathrm{a}$ & $100 \mathrm{a}$ & $0.00 \mathrm{~b}$ & $0.00 \mathrm{~b}$ \\
\hline & $\%$ leaf infection & $100 \mathrm{a}$ & $88.33 \mathrm{~b}$ & $0.00 \mathrm{c}$ & $0.00 \mathrm{c}$ \\
\hline & No. of lesion/leaf & $15.70 \mathrm{a}$ & $16.15 \mathrm{a}$ & $0.00 \mathrm{~b}$ & $0.00 \mathrm{~b}$ \\
\hline & Lesion size $\left(\mathrm{mm}^{2}\right)$ & $12.47 \mathrm{a}$ & $10.66 \mathrm{a}$ & $0.00 \mathrm{~b}$ & $0.00 \mathrm{~b}$ \\
\hline & Disease severity & $7.95 \mathrm{a}$ & $8.00 \mathrm{a}$ & $0.00 \mathrm{~b}$ & $0.00 \mathrm{~b}$ \\
\hline
\end{tabular}

*In a row, means followed by the same letter are not significantly different at the $5 \%$ level.
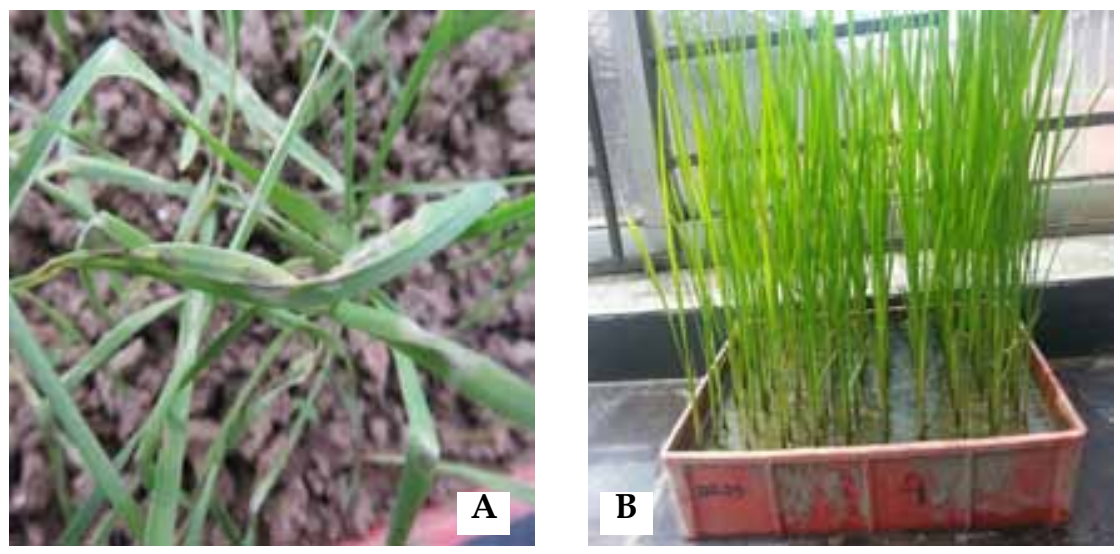

Fig. 1. Blast infected wheat leaves and disease free rice A. Blast symptom on wheat (BARI Gom25) leaves B. No blast symptom on rice (BRRI dhan29) leaves.
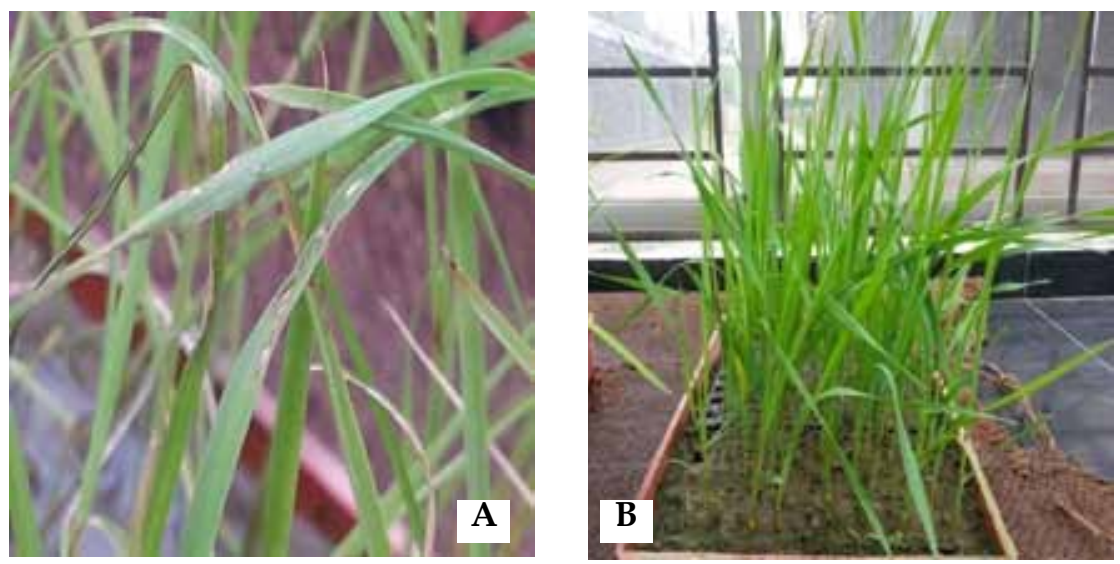

Fig. 2. Blast symptom on rice leaves and disease free wheat plants A. Blast symptom on rice (LTH) leaves B. No blast symptom on wheat (BARI Gom26) leaves. 
Pathogenicity of rice blast isolates on rice and wheat plants (single crop culture)

Both of the rice blast isolates RBL332 and RBL333 developed typical leaf blast symptoms on rice varieties BRRI dhan 29 and LTH (Fig. 2) and also caused maximum (100\%) plant infection (Table 2). However, the isolate RBL332 produced significantly higher degree of leaf infection $(83.33 \%)$ in a typical blast susceptible rice variety LTH compared to BRRI dhan29 (52.50\%). On the other hand, the isolate RBL333 caused significantly higher degree of leaf infection $(74.17 \%)$ in BRRI dhan29 compared to LTH $(52.50 \%)$. Average lesion number per leaf was 4.65 with RBL332 and 5.25 with RBL333 (Table 2). However, the lesion size was almost similar $\left(\sim 4.00 \mathrm{~mm}^{2}\right)$ with both the isolates. The highest disease severity index was for the isolate RBL332 was 7.50 in the scale of 9 and that for RBL333 was 6.20 (Table 2).

Pathogenicity of wheat blast isolates in ricewheat mixed crop culture

In rice-wheat mixed crop culture, the wheat blast isolates WBL002 and WBL0011 caused severe blast infection on both the wheat varieties BARI Gom 25 and BARI Gom 26 only (Fig. 3), which was similar to that observed in case of single cropping. Both of the isolates caused the highest level $(100 \%)$ of wheat plant infection (Table 3). Leaf infection was also high $(97.50-100 \%)$. Average numbers of leaf blast lesions were almost identical $(\sim 13.00)$ for both of the wheat blast isolates. However, larger $\left(10.94 \mathrm{~mm}^{2}\right)$ lesion was observed with WBL0011 and compared to the fungal isolate WBL002 $\left(7.79 \mathrm{~mm}^{2}\right)$. Disease severity index were recorded as 7.85 and 8.60 in the scale of 9 with the isolates WBL002 and WBL0011, respectively. Wheat isolate WBL0011 showed virulent reaction when compared with WBL002 isolate in case of percent leaf infection 100 and 84.17 in BARI Gom 25 and BARI Gom26, respectively. However, wheat isolate WBL0011 produced the highest number of lesion per leaf 18.55 in BARI Gom26 and bigger lesion size $\left(10.55 \mathrm{~mm}^{2}\right)$ was found in BARI Gom25. In contrast, the wheat isolates WBL002 and WBL0011 did not develop any blast symptom on the blast susceptible rice varieties BRRI dhan29 and LTH.

Pathogenicity of rice blast isolates in ricewheat mixed crop culture

The rice blast isolates RBL332 and RBL333 caused severe rice leaf blast symptom on BRRI dhan29 and LTH but no disease reaction on BARI Gom 25 and BARI Gom26 (Fig. 4). They caused 100 percent plant infection in BRRI dhan29 and LTH (Table 4). Number of lesions per leaf was 3.95 in BRRI dhan29 and 5.10 in LTH with RBL332 isolate. Lesion number and

Table 2. Effect of rice isolates on wheat and rice varieties with single cropping method.

\begin{tabular}{|c|c|c|c|c|c|}
\hline \multirow{2}{*}{ Isolate } & \multirow{2}{*}{ Parameter } & \multicolumn{2}{|c|}{ Wheat } & \multicolumn{2}{|c|}{ Rice } \\
\hline & & BARI Gom25 & BARI Gom26 & BRRI dhan29 & LTH \\
\hline \multirow[t]{5}{*}{ RBL332 } & $\%$ plant infection & $0.00 \mathrm{~b}$ & $0.00 \mathrm{~b}$ & $100 \mathrm{a}$ & $100 \mathrm{a}$ \\
\hline & $\%$ leaf infection & $0.00 \mathrm{c}$ & $0.00 \mathrm{c}$ & $52.50 \mathrm{~b}$ & $83.33 \mathrm{a}$ \\
\hline & No. of lesion/ leaf & $0.00 \mathrm{~b}$ & $0.00 \mathrm{~b}$ & $4.65 \mathrm{a}$ & $4.00 \mathrm{a}$ \\
\hline & Lesion size $\left(\mathrm{mm}^{2}\right)$ & $0.00 \mathrm{~b}$ & $0.00 \mathrm{~b}$ & $4.00 \mathrm{a}$ & $3.38 \mathrm{a}$ \\
\hline & Disease severity & $0.00 \mathrm{c}$ & $0.00 \mathrm{c}$ & $7.50 \mathrm{a}$ & $6.20 \mathrm{~b}$ \\
\hline \multirow[t]{5}{*}{ RBL333 } & $\%$ plant infection & $0.00 \mathrm{~b}$ & $0.00 \mathrm{~b}$ & $100 \mathrm{a}$ & $100 \mathrm{a}$ \\
\hline & $\%$ leaf infection & $0.00 \mathrm{c}$ & $0.00 \mathrm{c}$ & $74.17 \mathrm{a}$ & $52.50 \mathrm{~b}$ \\
\hline & No. of lesion/leaf & $0.00 \mathrm{~b}$ & $0.00 \mathrm{~b}$ & $5.25 \mathrm{a}$ & $4.00 \mathrm{a}$ \\
\hline & Lesion size $\left(\mathrm{mm}^{2}\right)$ & $0.00 \mathrm{~b}$ & $0.00 \mathrm{~b}$ & $3.98 \mathrm{a}$ & $4.03 \mathrm{a}$ \\
\hline & Disease severity & $0.00 \mathrm{~b}$ & $0.00 \mathrm{~b}$ & $5.65 \mathrm{a}$ & $6.20 \mathrm{a}$ \\
\hline
\end{tabular}

*In a row, means followed by the same letter are not significantly different at the $5 \%$ level. 
Table 3. Effect of wheat isolates on rice wheat mixed cropping.

\begin{tabular}{|c|c|c|c|c|c|}
\hline \multirow{2}{*}{ Isolate } & \multirow{2}{*}{ Parameter } & \multicolumn{2}{|c|}{ Rice + wheat } & \multicolumn{2}{|c|}{ Rice + wheat } \\
\hline & & BARI Gom25 (Wheat) & BRRI dhan29 (Rice) & BARI Gom26 & LTH (Rice) \\
\hline \multirow[t]{5}{*}{ WBL002 } & $\%$ plant infection & $100 \mathrm{a}$ & $0.00 \mathrm{~b}$ & $100 \mathrm{a}$ & $0.00 \mathrm{~b}$ \\
\hline & $\%$ leaf infection & $97.50 \mathrm{a}$ & $0.00 \mathrm{c}$ & $84.17 \mathrm{~b}$ & $0.00 \mathrm{c}$ \\
\hline & No. of lesion/leaf & $13.45 \mathrm{a}$ & $0.00 \mathrm{~b}$ & $14.70 \mathrm{a}$ & $0.00 \mathrm{~b}$ \\
\hline & Lesion size $\left(\mathrm{mm}^{2}\right)$ & $7.79 \mathrm{~b}$ & $0.00 \mathrm{c}$ & $10.83 \mathrm{a}$ & $0.00 \mathrm{c}$ \\
\hline & Disease severity & $7.85 \mathrm{a}$ & $0.00 \mathrm{~b}$ & $8.00 \mathrm{a}$ & $0.00 \mathrm{~b}$ \\
\hline \multirow[t]{5}{*}{ WBL0011 } & $\%$ plant infection & $100 \mathrm{a}$ & $0.00 \mathrm{~b}$ & $100 \mathrm{a}$ & $0.00 \mathrm{~b}$ \\
\hline & $\%$ leaf infection & $100 \mathrm{a}$ & $0.00 \mathrm{~b}$ & 89.17 b & $0.00 \mathrm{~b}$ \\
\hline & No. of lesion/leaf & $13.30 \mathrm{~b}$ & $0.00 \mathrm{c}$ & $18.55 \mathrm{a}$ & $0.00 \mathrm{c}$ \\
\hline & Lesion size $\left(\mathrm{mm}^{2}\right)$ & $10.94 \mathrm{a}$ & $0.00 \mathrm{~b}$ & $9.98 \mathrm{a}$ & $0.00 \mathrm{~b}$ \\
\hline & Disease severity & $8.6 \mathrm{a}$ & $0.00 \mathrm{~b}$ & $8.00 \mathrm{a}$ & $0.00 \mathrm{~b}$ \\
\hline
\end{tabular}

*In a row, means followed by the same letter are not significantly different at the $5 \%$ level.

Table 4. Effect of rice isolates on rice-wheat mixed cropping.

\begin{tabular}{|c|c|c|c|c|c|}
\hline \multirow{2}{*}{ Isolate } & \multirow{2}{*}{ Parameter } & \multicolumn{2}{|c|}{ Rice + wheat } & \multicolumn{2}{|c|}{ Rice + wheat } \\
\hline & & BARI Gom25 (Wheat) & BRRI dhan29 (Rice) & BARI Gom 26 (Wheat) & LTH (Rice) \\
\hline \multirow[t]{3}{*}{ RBL332 } & $\%$ plant infection & $0.00 \mathrm{~b}$ & $100 \mathrm{a}$ & $0.00 \mathrm{~b}$ & $100 \mathrm{a}$ \\
\hline & No. of lesion/leaf & $0.00 \mathrm{~b}$ & $3.95 \mathrm{~b}$ & $0.00 \mathrm{~b}$ & $5.10 \mathrm{a}$ \\
\hline & Lesion size $\left(\mathrm{mm}^{2}\right)$ & $0.00 \mathrm{~b}$ & $2.30 \mathrm{~b}$ & $0.00 \mathrm{~b}$ & $5.69 \mathrm{a}$ \\
\hline \multirow[t]{4}{*}{ RBL333 } & $\%$ plant infection & $0.00 \mathrm{~b}$ & $100 \mathrm{a}$ & $0.00 \mathrm{~b}$ & $100 \mathrm{a}$ \\
\hline & $\%$ leaf infection & $0.00 \mathrm{~b}$ & $80.83 \mathrm{a}$ & $0.00 \mathrm{~b}$ & $89.25 \mathrm{a}$ \\
\hline & No. of lesion/leaf & $0.00 \mathrm{c}$ & $4.65 \mathrm{~b}$ & $0.00 \mathrm{c}$ & $7.55 \mathrm{a}$ \\
\hline & Lesion size $\left(\mathrm{mm}^{2}\right)$ & $0.00 \mathrm{c}$ & $2.92 \mathrm{~b}$ & $0.00 \mathrm{c}$ & $5.28 \mathrm{a}$ \\
\hline
\end{tabular}

*In a row, means followed by the same letter are not significantly different at the $5 \%$ level.

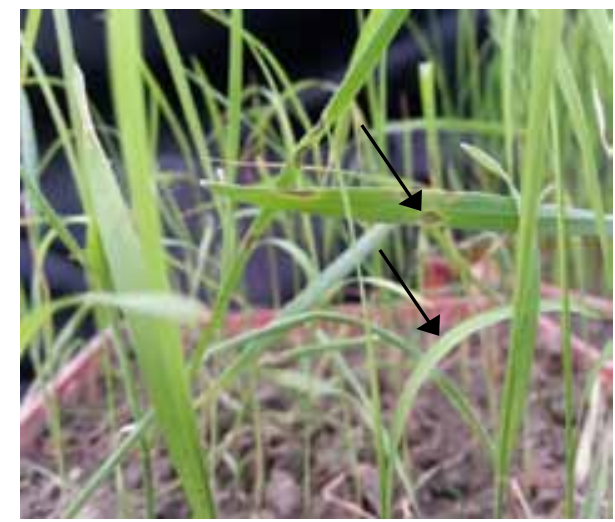

Fig. 3. Infected wheat leaves (red arrow) and healthy rice leaves (blue arrow) in mixed rice and wheat cropping method.

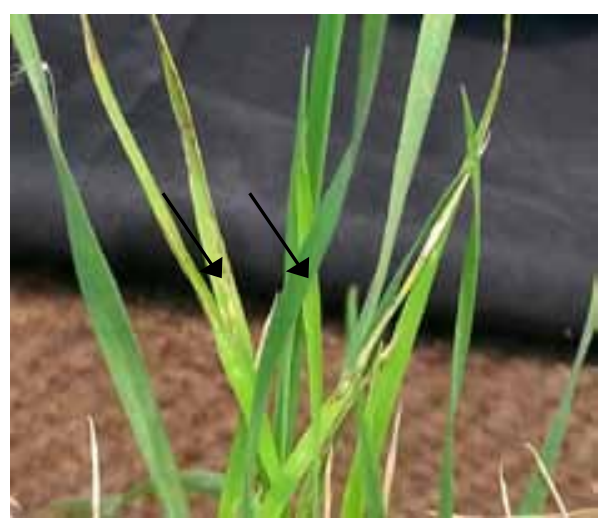

Fig. 4. Infected rice leaves (red arrow) and healthy wheat leaves (blue arrow) in mixed cropping method. 
lesion size were higher in both the isolates in LTH rice variety. Lesion number per leaf was 5.10 for RBL332 isolate and 7.55 for RBL333 isolate in LTH (Table 4). In case of RBL333 isolate, lesion size was $2.92\left(\mathrm{~mm}^{2}\right)$ and 5.28 $\left(\mathrm{mm}^{2}\right)$ respectably for in BRRI dhan29 and LTH. Disease severity scale was 5.10 with RBL332 and 7.4 with RBL333 isolate in LTH.

\section{DISCUSSION}

Rice blast is one of the most devastating diseases of rice in Bangladesh and throughout rice growing areas of the world. It threatens the stability of rice production worldwide. Plant pathogenic fungi have been suggested or demonstrated to have strategies for generating genetic variations, which enable them to adapt on resistant host by gaining pathogenicity to new hosts (Oliver, 2012). Pyricularia spp. possesses higher genetic changing ability and host diversification, for this reason degree of yield loss level is much more than other fungal pathogen. Normally blast disease found in rice but this year in March, 2016 blast disease were found in wheat in north-western part of Bangladesh. Wheat blast was first found in South America (Kohli et al., 2011).

In glasshouse experiments, variations on expression of blast disease symptoms were found in wheat and rice seedlings by artificial inoculation. It was found that wheat blast pathogen developed blast symptoms on wheat leaves, stem and junction of leaf blade and leaf sheath, but did not develop any blast symptom on any part of rice plants. Similarly, rice blast fungus developed blast symptoms only on rice leaves but not produced any disease symptom in any part of wheat plants. Couch et al., 2005 and Tredway et al., 2005 claimed that fungal isolates collected in nature belong to the pathotype specialized for the host species from which they were collected, indicating that cross infection is rare in nature.

Although host specific blast symptoms were observed with wheat and rice blast fungi, disease severity were higher in wheat seedlings when compared with rice seedlings. All parameters such as percent plant infection, percent leaf infection, lesion number per leaf, lesion size and disease score were higher in wheat seedlings comparatively to rice. Chromosomal constituent of wheat and rice blast pathogen bears some difference, so they do not cause compatible reaction on wheat and rice plants. Farman (2002), Tosa et al., 2004 and Viji et al., 2001 concluded that rice isolates differed from wheat isolates in containing a distinct set of transposable elements, but wheat and ryegrass isolates share the same set of transposable elements and are extremely closely related. Klaubauf et al. (2014) suggested that wheat blast pathogen and rice blast pathogen may represent distinct species. Paulo et al. (2015) have sequenced 10 genes in 121 Pyricularia spp. strains showing divergence between strains infecting wheat $(97$ strains) and rice (24 strains) and concluded that wheat blast isolates do not infect rice, but they all infect barley. In a project report of Kansus State University B. Valent (2016) claimed that P. grisea, P. oryzae Tritici and P. oryzae Lolium isolates are closely related and relatively distant from $P$. oryzae populations. They also found that $P$. oryzae Tritici isolates show a surprising degree of SNP (Single Nucleotide Polymorphism) ability relative to other blast pathogens.

\section{CONCLUSION}

Wheat blast disease was observed in the Southwestern Part of Bangladesh in 2016. This is also the first report of the disease in Asia. In this study, it was investigated whether the rice blast fungus could cause wheat blast symptoms and vice-versa. The study found that the isolates of rice blast fungus produced blast symptoms only on rice plant but not on wheat under both single and rice-wheat mixed crop culture. Similarly, the wheat blast fungus developed typical blast symptoms only on wheat varieties but not on rice. These preliminary findings discard the hypothesis of cross infection between rice and 
wheat blast fungi and also indicate the potential introduction or evolution of wheat blast fungus in Bangladesh.

\section{ACKNOWLEDGEMENT}

Authors thanks to Bangladesh Rice Research Institute (BRRI) authority for their continuous support to this study. Dr M U Salam and Prof. B Meah of Bangladesh Agricultural University are duly acknowledged for providing blast infected wheat samples. Technical staffs of Plant Pathology Division, BRRI are acknowledged for providing technical support service.

\section{REFERENCES}

Couch, B C and L M Kohn. 2002. A multilocus gene geneology concordant with host preference indicates segregation of a new species, Magnaporthe oryzae from Magnaporthe grisea. Mycologia 94: 683-693.

Couch, BC, I Fudal, M H Lebrun, D Tharreau and B Valent. 2005. Origins of host-specific populations of the blast pathogen Magnaporthe oryzae in crop domestication with subsequent expansion of pandemic clones on rice and weeds of rice. Genetics 170: 613-630.

Cruz, C D, J Kiyuna, W W Bockus, T C Todd, J P Stack and B Valent. 2015. Magnaporthe oryzae conidia on basal wheat leaves as a potential source of wheat blast inoculum. Plant Pathol. 64:1491-1498. doi:10.1111/ ppa.12414

Cruz, C D, G L Peterson, W W Bockus, P Kankanala, J Dubcovsky, K W Jordan, E Akhunov, F Chumley, F D Baldelomar and B Valent. 2016. The 2NS Translocation from Aegilops ventricosa Confers Resistance to the Triticum Pathotype of Magnaporthe oryzae. Crop Sci. 56(3): 990-1000

Dean R, J A L Van Kan, Z A Pretorius, K E Kosack, APietro, P D Spanu, J JRudd, M Dickman, R Kahmann, J Ellis and G D Foster. 2012. The top 10 fungal pathogens in molecular plant pathology. Mol. Plant. Pathol. 13: 414-430.

Duveiller, E, P K Singh, M Mezzalama, R P Singh and A Dababat. 2012. Wheat Diseases and Pests: A Guide for Field Identification (2nd Edition). CIMMYT. Mexico, D F., Mexico.

Farman, M L. 2002. Pyriculariagriseaisolates causing gray leaf spot on perennial ryegrass (Loliumperenne) in the United States: Relationship to $P$ grisea isolates from other host plants. Phytopathol. 92: 245-254. doi: 10.1094/PHYTO.2002.92.3.245
Fatemi, J and RR Nelson. 1978. Inter isolate heterokaryosis in Pyricularia oryzae. Phytopathol. 68: 1791-1794.

Goulart, A, and F Paiva. 2000. Perdas no rendimiento de grãos de trigocausadaporPyriculariagrisea, nosanos de 1991 e 1992, no Mato Grosso do Sul. (In Portuguese.) Summa Phytopathol. 26: 279-282.

Goulart, A, F Paiva, and NMesquita. 1992. Perdas en trigo (Triticum aestivum) causadaspor Pyricularia oryzae. (In Portuguese.) Fitopatol. Bras. 17: 115-117.

Goulart, A C P, P G Sousa and A S Urashima. 2007. Damages in wheat caused by infection of Pyricularia grisea. (In Portuguese.) Summa Phytopathol. 33: 358-363. doi: 10.1590/S0100-54052007000400007

Igarashi, S. 1991. Update on wheat blast (Pyricularia oryzae) in Brazil. In: D. Saunders, editor, Wheat for the nontraditional warm areas. Proc. Intl. Conf. Foz Do Iguaçu, Brazil. 29 July-3 Aug. 1990. p. 480-483.

Igarashi, S, C M Utiamada, L C Igarashi, A H Kazuma and R S Lopes. 1986. Pyricularia emtrigo. 1. Ocorrência de Pyricularia sp. noestado do Paraná. (In Portuguese.) Fitopatol. Bras. 11: 351-352.

Kato, H, M Yamamoto, T Yamaguchi-ozaki, H Kadouchi, Y Iwamoto, H Nakayashiki, Y Tosa, S Mayama, N Mori. 1994. Pathogenecity, mating ability and DNA restriction fragment length polimorphisms of Pyricularia populations isolated from Gramineae, Bambusideae and Zingiberaceae plants. J. Gen. Plant. Pathol. 66: 30-47

Khan, M A I,_M A Ali, M A Monsur, A K Tanaka, N Hayashi, S Yanagihara, M Obara, M A T Mia, M A Latif and Y Fukuta. 2016. Diversity and Distribution of Rice Blast (Pyricularia oryzae Cavara) Races in Bangladesh. Plant dis. 100: 2025-2033

Klaubauf S, Tharreau D and Fournier E. 2014. Resolving the polyphyletic nature of Pyricularia (Pyriculariaceae). Studies in Mycology 79: 85-120.

Kihoro, J, J B Njoroge, H Murage, E Ateka, and D Makihara. 2013. Investigating the impact of rice blast disease on the livelihood of the local farmers in greater Mwea region of Kenya. Springer plus. 2: 308

Kohli, M M, Y R Mehta, E Guzman, L D Viedma and L E Cubilla. 2011. Pyricularia blast - A threat to wheat cultivation. Czech J. Genet. Plant Breed. 47: S130-S134

Maciel, J L N, P C Ceresini, V L Castroagudin, M Zala, G H J Kema and B A McDonald. 2014. Population structure and pathotype diversity of the wheat blast pathogen Magnaporthe oryzae 25 years after its emergence in Brazil. Phytopathol. 104: 95-107. doi: 10.1094/PHYTO-11-12-0294-R

Monsur M A , M Ahmed, A Haque, QS A Jahan, T H Ansari, M A Latif, N C D Borma, M A Ali, M S Kabir and B R Banik. 2016. Research update of cross infection between rice and wheat blast at BRRI. Presented on 27 October Bangladesh Agricultural Research Council (BARC), Dhaka, Bangladesh.

Oliver R P. 2012. Genomic tillage and the harvest of fungal phytopathogens. New Phytologist. 196: 1015-1023. 
Orbach, J, F Chumley and B Valent. 1996. Electrophoretic karyotypes of Magnaporthe grisea pathogens of diverse grasses. Mol. Plant-Microbe Interact. 9: 261271. doi: 10.1094/MPMI-9-0261

Paulo, C C, L C Vanina, L N M Joao and A M Bruce. 2015. The recent emergence of wheat blast in Brazil.McDonald_Wheat_Blast_Asilomar_Fungal_ Genetics. 10 (1).

Prabhu, A, M Filippi and N Castro. 1992. Pathogenic variation among isolates of Pyricularia oryzae infecting rice, wheat and grasses in Brazil. Trop. Pest Manage. 38: 367-371. doi: 10.1080/09670879209371729.

The Daily Star. 2016. Deadly wheat blast came from Brazil. The Daily Star, Bangladesh. 26 May 2016.

Tiedemann, A V. 2016. Mitigating the Threat of Wheat Blast in Bangladesh and Beyond. Regional Consultation Workshop on July 26-27, Kathmandu, Nepal.

Tosa, Y, K Hirata, H Tamba, S Nakagawa, I Chuma, C Isobe, J Osue,A S Urashima, L D Don, M Kusaba. 2004. Genetic constitution and pathogenicity of Lolium isolates of Magnaporthe oryzae in comparison with host species-specific pathotypes of the blast fungus. Phytopathol. 94: 454-462.
Tredway, L P, K L Stevenson and L L Burpee. 2005. Genetic structure of Magnaporthe grisea populations associated with St. Augustine grass and tall fescue in Georgia. Phytopathol. 95: 463-471

Urashima, A S, W W Bockus, R L Bowden, R M Hunger, W L Morrill, T D Murray and R W Smiley. 2010. Compendium of wheat diseases and pests. American Phytopathological Society, Saint Paul, MN. p. 22-23.

Urashima, A S, Y Hashimoto, L Don, M Kusaba, Y Tosa, H Nakayashiki and S Mayama. 1999. Molecular analysis of the wheat blast population in Brazil with a homolog of retrotransposon MGR583. J. Phytopathol. 65: 429-436. doi: 10.3186/ jjphytopath.65.429

Viji, G, B Wu, S Kang, W Uddin and D R Huff. 2001. Pyricularia grisea causing gray leaf spot of perennial ryegrass turf: population structure and host specificity. Plant Disease 85: 817-826.

Valent B. 2016. Novel strategies for managing blast diseases on rice and wheat. National Institute of Food and Agriculture (project report). Manhattan, KS 66506. 
